\title{
P2X7 receptors exert a permissive effect on the activation of presynaptic AMPA receptors in rat trigeminal caudal nucleus glutamatergic nerve terminals
}

Diego Currò, Pierluigi Navarra, Irene Samengo and Maria Martire*

\begin{abstract}
Background: Purine receptors play roles in peripheral and central sensitization and are associated with migraine headache. We investigated the possibility that ATP plays a permissive role in the activation of AMPA receptors thus inducing Glu release from nerve terminals isolated from the rat trigeminal caudal nucleus (TCN).

Methods: Nerve endings isolated from the rat TCN were loaded with $\left[{ }^{3} \mathrm{H}\right] \mathrm{D}$-aspartic acid $\left(\left[^{3} \mathrm{H}\right] \mathrm{D}-\mathrm{ASP}\right)$, layered into thermostated superfusion chambers, and perfused continuously with physiological medium, alone or with various test drugs. Radioactivity was measured to assess [ $\left.{ }^{3} \mathrm{H}\right] \mathrm{D}$-ASP release under different experimental conditions.

Results: Synaptosomal $\left.{ }^{3} \mathrm{H}\right] \mathrm{D}$-ASP spontaneous release was stimulated by ATP and to an even greater extent by the ATP analogue benzoylbenzoylATP (BzATP). The stimulation of [ $\left.{ }^{3} \mathrm{H}\right] \mathrm{D}$-ASP basal release by the purinergic agonists was prevented by the selective P2X7 receptor antagonist A438079. AMPA had no effect on basal $\left[^{3} \mathrm{H}\right] \mathrm{D}$-ASP release, but the release observed when synaptosomes were exposed to AMPA plus a purinoceptor agonist exceeded that observed with ATP or BzATP alone. The selective AMPA receptor antagonist NBQX blocked this "excess" release. Coexposure to AMPA and BzATP, each at a concentration with no release-stimulating effects, evoked a significant increase in $\left.{ }^{3} \mathrm{H}\right] \mathrm{D}$-ASP basal release, which was prevented by exposure to a selective AMPA antagonist.

Conclusions: P2X7 receptors expressed on glutamatergic nerve terminals in the rat TCN can mediate Glu release directly and indirectly by facilitating the activation of presynaptic AMPA receptors. The high level of glial ATP that occurs during chronic pain states can promote widespread release of Glu as well as can increase the function of AMPA receptors. In this manner, ATP contributes to the AMPA receptor activation involved in the onset and maintenance of the central sensitization associated with chronic pain.
\end{abstract}

Keywords: P2X7 receptor, AMPA receptors, Trigeminal caudal nucleus, Synaptosomes, $\left[{ }^{3} \mathrm{H}\right] \mathrm{D}$-aspartic acid release, Central sensitization, Nociceptive circuit

\footnotetext{
* Correspondence: maria.martire@unicatt.it

Institute of Pharmacology, School of Medicine, Università Cattolica del Sacro

Cuore, Largo Francesco Vito, 1, 00168 Rome, Italy
}

(C) The Author(s). 2020 Open Access This article is licensed under a Creative Commons Attribution 4.0 International License, which permits use, sharing, adaptation, distribution and reproduction in any medium or format, as long as you give appropriate credit to the original author(s) and the source, provide a link to the Creative Commons licence, and indicate if changes were made. The images or other third party material in this article are included in the article's Creative Commons licence, unless indicated otherwise in a credit line to the material. If material is not included in the article's Creative Commons licence and your intended use is not permitted by statutory regulation or exceeds the permitted use, you will need to obtain permission directly from the copyright holder. To view a copy of this licence, visit http://creativecommons.org/licenses/by/4.0/ The Creative Commons Public Domain Dedication waiver (http://creativecommons.org/publicdomain/zero/1.0/) applies to the data made available in this article, unless otherwise stated in a credit line to the data. 


\section{Background}

ATP is known to be an important mediator of signal transmission through the spinal nociceptive circuits [1]. Its release by neurons and glial cells of these circuits impacts the activity of nearby cells by binding ligand-gated cation channels (P2X) or metabotropic (P2Y) receptors [2]. ATP interaction with P2X7 receptors elicits a dualmode response, consisting of the rapid opening of a channel permeable to small cations (within milliseconds of binding) followed by the opening of a larger pore (seconds after ATP binding) through which molecules with a mass of up to $900 \mathrm{Da}$ can flow. The second phase of the response appears to be mediated by the recruitment of additional pore-forming proteins, usually pannexin-1 (PANX1) but also connexins [3].

P2X7 receptors are widely expressed by several cell types involved in pain transmission, including the neurons, microglia, satellite glial cells, and astrocytes located in the dorsal root ganglia, the trigeminal ganglia, and in the dorsal horn of the spinal cord [4]. P2X7-knockout mice display a lack of hypersensitivity to mechanical and thermal stimuli [5], and P2X7-specific antagonists have consistently been found to produce protective effects in animal models of inflammatory and neuropathic pain [6]. In addition, selective centrally penetrant P2X7 antagonists are emerging as promising therapeutic agents, since the density of P2X7 receptors in healthy tissue is quite low [7]. ATP interacts with the neurotransmitters GABA and glutamate (Glu), and it has been shown to facilitate glutamatergic transmission in the spinal and medullary dorsal horn areas [8-10]. P2X7 receptors are found on excitatory nerve terminals in different areas of the CNS, including the medulla oblongata, spinal cord and nodose ganglia [11]. In the rat brain, $\mathrm{P} 2 \mathrm{X} 7$ receptors are co-localized in nerve terminals with the vesicular Glu transporters vGLUT1 and vGLUT2 [12], and they have been shown to trigger Glu release by astrocytes [13] as well as neurons [14].

In this study, we examined interactions between P2X7 receptors and AMPA receptors co-expressed on primary afferents that from trigeminal ganglion (TG) project into the trigeminal caudal nucleus (TCN) of the rat brain. The TCN receives sensory input from the face and the head, including primary afferent $\mathrm{A} \delta$ - and $\mathrm{C}$-fibers from the meningeal vessels. It is the first central relay station in the orofacial and head pain pathway. It contains second-order neurons whose nerve endings project into higher nerve centers and excitatory and inhibitory interneurons [15]. Nerve endings can be isolated from the rat TCN tissues that are presumably the glutamatergic terminals of both primary afferents and excitatory interneurons present in the TCN.

The nucleus caudalis of the trigeminal spinal tract is widely acknowledged to play an integral role in the brain stem processing of orofacial and head nociceptive signals, including those involved in migraine headache [16]. ATP and its catabolites are involved in various aspects of the initiation and transmission of migraine pain, including vasomotor mechanisms, cortical spreading depression, and fast transmission in neurons and glial cells [17]. The contributions of purinergic signaling to the transmission of migraine pain involves the activation of both P2X and P2Y receptors. Among P2X receptors, $\mathrm{P} 2 \mathrm{X} 3$ receptors are almost exclusively expressed in nociceptive neurons, suggesting that they are involved specifically in the transmission of pain signals $[18,19]$. P2X3 receptors interact with calcitonin gene-related peptide (CGRP), a central player in migraine pathogenesis [20], to trigger and amplify migraine pain. The trigeminal sensory neurons that innervate the meninges usually contain CGRP and express P2X3 receptors in their peripheral and central terminals as well [21]. The activation of P2X3 receptors facilitates the release of CGRP within the dura mater, thus promoting the initiation of inflammatory processes, and in the trigeminal nuclei of the brainstem [22]. CGRP causes sensitization of the nociceptive P2X3 receptors in the TG [23]. In addition, CGRP increases the levels of the pronociceptive nucleotides ATP and ADP in various parts of the trigeminal nociceptive system and enhances the responses induced by low concentrations of ATP [24]. While P2X3 receptors are involved in the initiation and transmission of a migraine attack, the metabotropic P2Y receptors seems to play modulatory roles in migraine pathophysiology [25]. The activation of P2Y13 metabotropic receptors causes contraction of the middle meningeal artery in vitro, reduces the dural artery dilation following periarterial electrical stimulation in vivo, and decreases CGRP release from both the dura and the trigeminal ganglion in situ. These are all opposite effects to those induced by P2X3 receptor activation, which include CGRP release and middle meningeal artery dilation [25]. P2X7 receptors also seem to play roles in the onset of migraine-associated neuroinflammatory events in the brain and meninges. Notably, migraine aura-related cortical spreading depression is associated with the opening of PANX1 channels, which are tightly coupled to P2X7 receptors, suggesting that a massive release of ATP occurs during a migraine attack [26, 27]. Furthermore, P2X7 receptors, that are ligand-gated ion channels that conduct $\mathrm{Na}^{+}$and $\mathrm{Ca}^{2+}[28]$, can trigger the exocytotic release of Glu, a features which is also compatible with their putative role in determining the susceptibility to the spreading depolarization.

In this study, we investigated the possibility that ATP co-released with Glu from rat TCN nerve terminals exerts a permissive effect on the activation of AMPA receptors that mediate Glu release. To this end, we 
assessed the release of pre-loaded $\left[{ }^{3} \mathrm{H}\right] \mathrm{D}$-aspartate $\left.\left[{ }^{3} \mathrm{H}\right] \mathrm{D}-\mathrm{ASP}\right)$ from superfused rat trigeminal synaptosomes. We found that the activation of ATP receptors belonging to the P2X7 subtype not only elicits Glu release, but also facilitates the activation of releaseenhancing AMPA receptors co-existing with P2X7 receptors on TCN glutamatergic terminals.

\section{Methods}

\section{Animals and synaptosomes preparation}

Adult male Wistar rats (weighing 200-250 g) (Animal Facility of Catholic University) were used in the study. Animal procedures were approved by the Ethics Committee of the Catholic University and were fully compliant with Italian (Ministry of Health guidelines, Legislative Decree No. 116/1992) and European (Directive No. 86/609/EEC) animal research legislation.

Animals were sacrificed, and the brain and upper portion of the spinal cord were rapidly removed and immersed in ice-cold medium (described in detail below). The cerebral cortex and cerebellum were discarded, and the tissue block containing the brainstem was sectioned at the level of the obex and $0.4 \mathrm{~cm}$ below the obex to isolate the brainstem segment containing the TCN [29]. The lateralmost portions (right and left) of this tissue block, which contained the TCN, were used to prepare crude synaptosomes, as previously described [30].

\section{Release experiments}

The synaptosome pellet was resuspended in standard perfusion medium, a physiological medium containing $(\mathrm{mmol} / \mathrm{L}) \mathrm{NaCl} 125, \mathrm{KCl} 3, \mathrm{MgSO}_{4}$ 1.2, $\mathrm{CaCl}_{2}$ 1.2, $\mathrm{NaH}_{2} \mathrm{PO} 4$ 1.0, $\mathrm{NaHCO}_{3}$ 22, and glucose 10 (oxygenated with $95 \% \mathrm{O}_{2} / 5 \% \mathrm{CO}_{2}, \mathrm{pH} 7.40$ ). The synaptosomes were then incubated in an atmosphere of $95 \% \mathrm{O}_{2} / 5 \% \mathrm{CO}_{2}$ for $15 \mathrm{~min}$ at $37^{\circ} \mathrm{C}$ with $0.03 \mu \mathrm{M}\left[{ }^{3} \mathrm{H}\right] \mathrm{D}$-ASP. Exogenously loaded $\left[{ }^{3} \mathrm{H}\right] \mathrm{D}$-ASP is widely used in synaptosomal release experiments as a marker for endogenously formed Glu since the two substances are similarly released, via an exocytotic $\mathrm{Ca}^{2+}$-dependent process, in response to 12 $\left.\mathrm{mM}\left[\mathrm{K}^{+}\right]_{\mathrm{e}}\right)$ [31]. Use of this mild depolarizing stimulus allows us to obtain a "clean" estimation of $\mathrm{Ca}^{2+}$. dependent Glu exocytosis, without the component mediated by the transporter reversal, which can occur when the extracellular $\mathrm{Na}^{+}$level is reduced to compensate for the increase in $\mathrm{K}^{+}$in the depolarizing medium [32].

Identical aliquots of the synaptosomal suspension were placed on $0.8 \mu \mathrm{m}$ Millipore filters at the bottom of a set of parallel superfusion chambers, which were maintained at $37^{\circ} \mathrm{C}$ [33]. The synaptosome suspension was then washed with $3 \times 10 \mathrm{ml}$ of standard medium at $37^{\circ} \mathrm{C}$ under moderate vacuum filtration and superfused at a rate of $0.6 \mathrm{ml} / \mathrm{min}$ with standard medium aerated with
95\% $\mathrm{O}_{2} / 5 \% \mathrm{CO}_{2}$. After a 38-min equilibration period, the synaptosomes were perfused with standard medium with or without test substances or depolarizing medium (standard medium subjected to equimolar substitution of $12 \mathrm{mM} \mathrm{NaCl}$ with $\mathrm{KCl}$ ) with or without test substances. Thereafter perfusion was continued with standard medium alone for different intervals, depending on the experimental protocol. Antagonists, when tested, were added to the medium $8 \mathrm{~min}$ before the agonists. The effect of lowering extracellular $\mathrm{Mg}^{2+}$ concentration was assessed in synaptosomes superfused with a medium containing $0.01 \mathrm{mmol} / \mathrm{L} \mathrm{MgSO}_{4}$, starting $18 \mathrm{~min}$ before addition of the agonist. More detailed descriptions of experimental methods are provided in the figure legends.

Superfusate fractions were collected every $2 \mathrm{~min}$, starting from min 38 of the pre-stimulation phase, and radioactivity was counted in each fraction as well as in the superfused synaptosomes themselves.

The amount of radioactivity found in a given superfusate fraction was expressed as a percentage of the total tritium present in the synaptosomes at the beginning of the respective collection period. These percentages were then plotted against perfusion time $(\mathrm{min})$ to evaluate the time-course of $\left[{ }^{3} \mathrm{H}\right] \mathrm{D}$-ASP release under different conditions. To evaluate the effects of test drugs, we compared the integrated areas under the time/release curves (AUCs) obtained in the presence of the test drug and under control conditions (assessed in parallel). The results were expressed as percentage increases or decreases relative to control values.

\section{Statistical analyses}

Reported data represent means \pm S.E.M. of the given number of experiments $(n)$.

Each experiment (i.e., $n=1$ ) was carried out using tissues isolated from the TCNs of five rats. We put together and homogenized the five TCNs (thereby annulling individual differences between one animal and another) to produce a single sample large enough to be layered onto the bases of multiple perfusion chambers. The mean of values observed under identical experimental conditions in 3 perfusion chambers was calculated and represents $1 \mathrm{n}$. A total of 120 rats were used for the 24 experiments conducted.

Analysis of variance was performed by ANOVA followed by Dunnett's multiple comparison test. $P$ values $<0.05$ were considered significant.

\section{Drugs}

D- $\left[2,3-{ }^{3} \mathrm{H}\right]$-aspartic acid $\left(\left[{ }^{3} \mathrm{H}\right] \mathrm{D}\right.$-ASP) (specific activity $11.30 \mathrm{Ci} / \mathrm{mmol}$ ) was purchased from Perkin Elmer Life and Analytical Sciences (Boston, MA, USA). Dihydrokainate; 6-chloro-3,4-dihydro-3-(5-norbornene-2-yl)-2H-1, 2,4-benzothiazidiazine-7-sulfonamide-1,1-dioxide 
(cyclothiazide); 2,3-dioxo-6-nitro-1,2,3,4-tetrahydrobenzo [f]quinoxaline-7-sulfonamide disodium salt (NBQX); adenosine $5^{\prime}$-triphosphate disodium salt (ATP); 2'-3'-O-(4-benzoylbenzoyl) adenosine 5'-triphosphate triethylammonium salt (BzATP); 3-[[5-(2,3dichlorophenyl)-1H-tetrazol-1-yl] methyl] pyridine hydrochloride (A438079) were purchased from Tocris Cookson (Bristol, United Kingdom). ( \pm )- $\alpha$-Amino-3-hydroxy-5-methylisoxazole-4-propionic acid hydrobromide (AMPA) was purchased from Sigma-Aldrich (St. Louis, MO, USA). Initially, we prepared stock solutions of AMPA and stored them at $-20^{\circ} \mathrm{C}$ until use, but their activity was found to decrease over time. The experiments reported below were therefore performed with AMPA solutions prepared from powder on the day of the experiment. When possible, drugs were dissolved in distilled water or in standard perfusion medium. Stock solutions of cyclothiazide (CTZ) were prepared in dimethyl sulfoxide and diluted at least 1:1000 in standard medium.

\section{Results}

Synaptosomes isolated from rat $\mathrm{TCN}$ and preloaded with $\left[{ }^{3} \mathrm{H}\right] \mathrm{D}$-ASP were superfused with standard medium or with standard medium followed by depolarizing medium. Typical time-courses of basal tritium release and that evoked by depolarization (12 $\left.\mathrm{mM}\left[\mathrm{K}^{+}\right]_{\mathrm{e}}\right)$ are illustrated in Fig. 1a. As shown in Fig. 1a, $1 \mathrm{mM}$ ATP stimulated basal release of $\left[{ }^{3} \mathrm{H}\right] \mathrm{D}$-ASP from synaptosomes, as well as that triggered by 12 $\mathrm{mM}\left[\mathrm{K}^{+}\right]_{\mathrm{e}}$. The highest concentration of ATP used (3 $\mathrm{mM}$ ) increased by $85 \pm 5 \%$ the basal $\left[{ }^{3} \mathrm{H}\right] \mathrm{D}$-ASP release.

The enhancement of basal release was more evident when synaptosomes were exposed to benzoylbenzoylATP (BzATP), a nonselective P2X receptor agonist whose potency in activating $\mathrm{P} 2 \mathrm{X} 7$ receptors (but not other P2X receptor subtypes) exceeds that of ATP by at least one order of magnitude [34]. At concentrations of 0.01-3 mM, the effects of BzATP were concentrationdependent (Fig. 1b) with an $\mathrm{EC}_{50}$ of $245 \pm 12.50 \mu \mathrm{M}(n=$ 3 ) and maximum enhancement of $152 \pm 6.50 \%$.

The activities of the various types of $\mathrm{P} 2 \mathrm{X}$ receptors are known to be influenced by divalent cation concentrations [35]. We therefore assessed the effects of extracellular $\mathrm{Mg}^{2+}$ levels on BzATP-evoked tritium release from the TCN synaptosomes. As shown in Fig. 1b, the concentration-response curve displayed a clear shift to the left when the $\mathrm{Mg}^{2+}$ level of the medium was reduced from $1.2 \mathrm{mmol} / \mathrm{L} \mathrm{Mg}^{2+}$ to $0.01 \mathrm{mmol} / \mathrm{L} \mathrm{Mg}^{2+}$ : in the low $\mathrm{Mg}^{2+}$ medium, the maximum effect was $148 \pm 10 \%$ and $\mathrm{EC}_{50}$ was $24 \pm 1.40 \mu \mathrm{M}(n=3)$.

As shown in Fig. 1c, the increases in $\left[{ }^{3} \mathrm{H}\right] \mathrm{D}$-ASP release induced by $1 \mathrm{mM}$ ATP or by $100 \mu \mathrm{M}$ BzATP were completely reversed by the selective P2X7-receptor antagonist A438079 (5 $\mu \mathrm{M})$.

Glutamatergic nerve terminals isolated from the rat TCN express autoreceptors for AMPA that can potentiate the $\left[{ }^{3} \mathrm{H}\right] \mathrm{D}$-ASP release induced by depolarization [10]. When synaptosomes were exposed in superfusion to $100 \mu \mathrm{M}$ AMPA in medium containing $12 \mathrm{mM}\left[\mathrm{K}^{+}\right]_{\mathrm{e}}$, a significant increase of $\left[\mathrm{K}^{+}\right]_{\mathrm{e}}$-evoked tritium release was observed (124 $\pm 7 \% ; n=3$ ) (Fig. 2a), although AMPA $(100 \mu \mathrm{M})$ had no significant effect on basal $\left[{ }^{3} \mathrm{H}\right] \mathrm{D}$-ASP release (Fig. 2a). The $100 \mu \mathrm{M}$ AMPA-induced potentiation of $\left[\mathrm{K}^{+}\right]_{\mathrm{e}}$-evoked $\left[{ }^{3} \mathrm{H}\right] \mathrm{D}$-ASP release was abolished by the selective AMPA antagonist NBQX $(10 \mu \mathrm{M})$ (Fig. $2 \mathrm{a})$, and it was significantly enhanced by cyclothiazide (CTZ) $(10 \mu \mathrm{M})$, an agent capable of inhibiting the rapid desensitization of AMPA receptors.

The dose-response curve with the various concentrations of AMPA $(0.1-300 \mu \mathrm{M})+10 \mu \mathrm{M}$ CTZ showed a maximum effect of $240 \pm 15 \%$ and an $\mathrm{EC}_{50}$ of $16 \pm$ $1.20 \mu \mathrm{M}(n=3)$ (Fig. 2b). Used alone at the concentrations tested, neither CTZ nor NBQX had any effect on $\left[\mathrm{K}^{+}\right]_{\mathrm{e}}$-evoked $\left[{ }^{3} \mathrm{H}\right] \mathrm{D}$-ASP release (data not shown).

The findings reported above suggest that P2X7 receptors and AMPA receptors on glutamatergic terminals in the TCN might be interacting to regulate the latters' release of Glu. To investigate this possibility, we measured $\left[{ }^{3} \mathrm{H}\right] \mathrm{D}$-ASP release from synaptosomes perfused with standard medium containing $100 \mu \mathrm{M}$ AMPA, with or without $1 \mathrm{mM}$ ATP. As shown in Fig. 3a, AMPA $(100 \mu \mathrm{M})$ alone had no effect on basal release, but when it was added to standard medium containing $1 \mathrm{mM}$ ATP, it appreciably potentiated the ATP-induced release of $\left[{ }^{3} \mathrm{H}\right] \mathrm{D}$-ASP, with an increase in basal release of $135 \pm$ $8.50 \%(n=3)$ vs the increase produced by $1 \mathrm{mM}$ ATP alone $(40 \pm 2.50 \% ; n=4)$. The potentiating effect of AMPA was abolished by the presence of the AMPA antagonist NBQX (10 $\mu \mathrm{M})$ (Fig. 3a).

Millimolar concentrations of ATP are reportedly necessary to produce functional effects mediated by P2X7 purinoceptors [34, 36]. Since such concentrations are likely to have multiple actions, our subsequent experiments were performed with BzATP, which is more potent than ATP in activating the P2X7 receptor subtype [34].

As shown in Fig. 3b, BzATP $10 \mu \mathrm{M}$ alone had no effect on the basal release of $\left[{ }^{3} \mathrm{H}\right] \mathrm{D}$-ASP by synaptosomes, but a significant increase was observed when BzATP was used at a concentration of $100 \mu \mathrm{M} \quad(42 \pm 8 \% ; n=3)$. When BzATP $(100 \mu \mathrm{M})$ was applied with AMPA $(100 \mu \mathrm{M})$, which had no effect on basal release when used alone, the increased release was significantly greater than that observed with BzATP alone (148 $\pm 9 \% ; n=3)$.

The potentiation of the BzATP-evoked release seen in the presence of AMPA was not observed when NBQX 


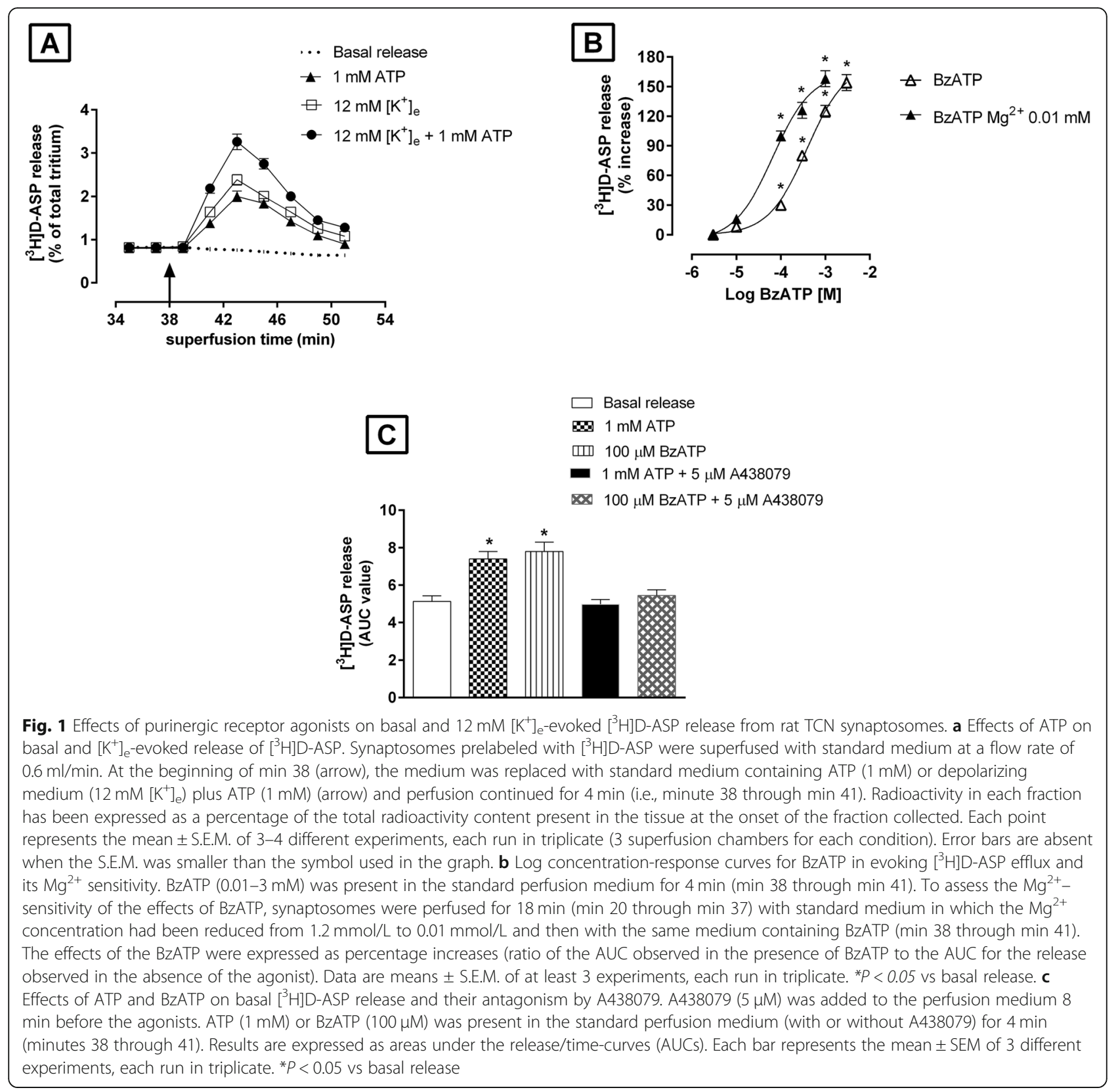

$(10 \mu \mathrm{M})$ was present in the superfusion medium, indicating that AMPA receptors are likely to be involved in this potentiation. The marked increase in basal $\left[{ }^{3} \mathrm{H}\right] \mathrm{D}$-ASP release induced by BzATP plus AMPA suggests that activation of purinergic receptors located on glutamatergic nerve endings in the TCN may facilitate the exposure of AMPA receptors located on the same nerve terminals.

To shed light on the mechanism of the interaction between P2X7 and AMPA receptors, we investigated the possibility that $\left[{ }^{3} \mathrm{H}\right] \mathrm{D}$-ASP release would be elicited by concomitant exposure to BzATP and AMPA, each used at concentrations that were per se inactive. As shown in Fig. 3b, addition to the superfusion solution of $10 \mu \mathrm{M}$
BzATP and $100 \mu \mathrm{M}$ AMPA provoked significant enhancement of basal $\left[{ }^{3} \mathrm{H}\right] \mathrm{D}$-ASP efflux $(35 \pm 2 \% ; n=3)$, an effect that was abolished by the AMPA antagonist NBQX $(10 \mu \mathrm{M})$ and also by the P2X7 receptor antagonist A438079 (5 $\mu \mathrm{M})$ (Fig. 3b).

\section{Discussion}

Glutamate plays major roles in the transmission and modulation of pain information in the trigeminal sensory system [37]. In addition, it is regarded as an important mediator of central sensitization that stems from changes in ionotropic NMDA and AMPA Glu receptors caused in part by the translocation of 


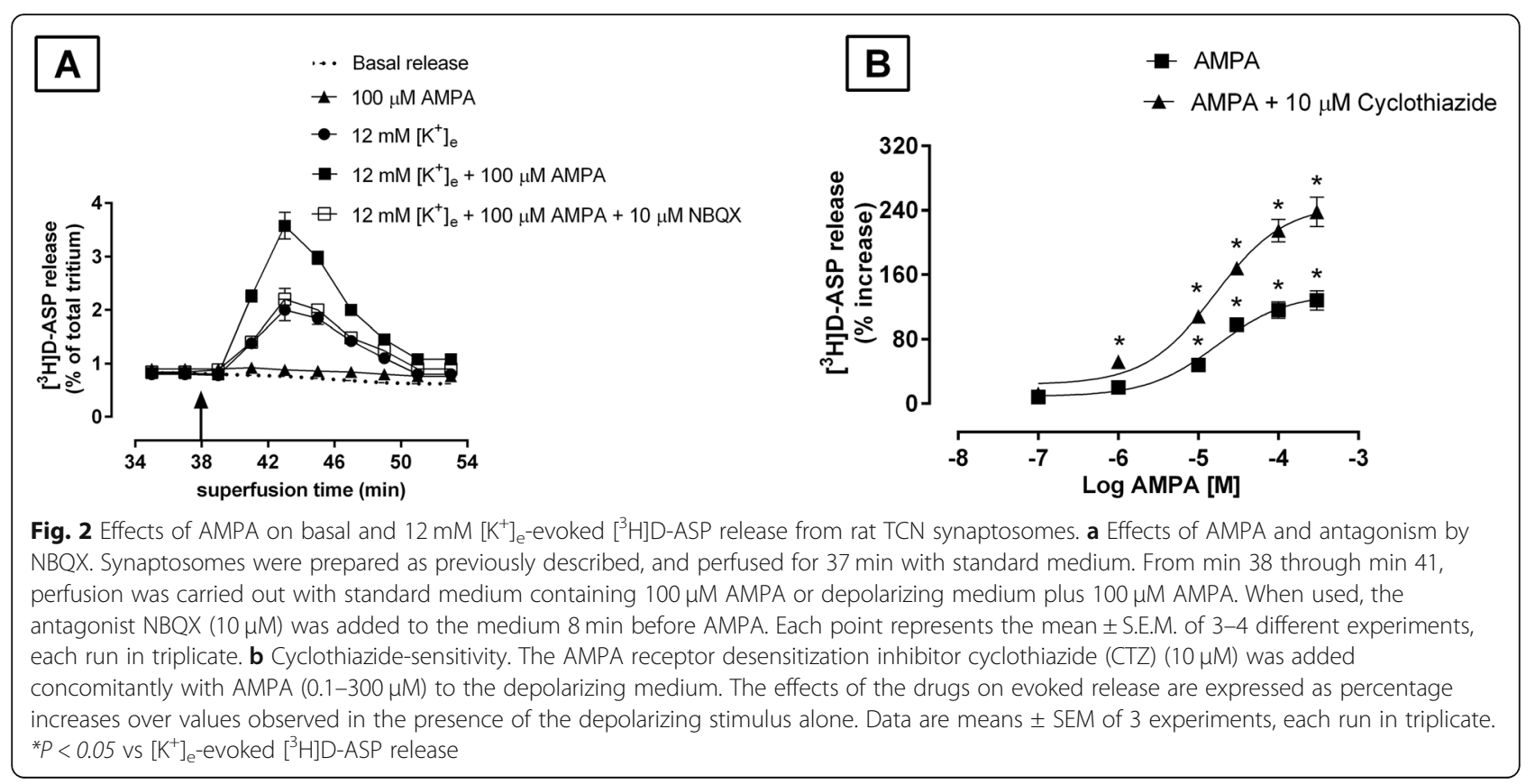

intracytoplasmic receptors to the membrane and in part by phosphorylation-mediated increase in receptor/ion channel function [38, 39]. Inhibition of spinal AMPA receptors has been shown to reverse the mechanical allodynia and the thermal and mechanical hypersensitivities associated with the development and maintenance of various types of pain [40, 41]. However, the therapeutic implications of these findings are limited in that blockade of AMPA receptors with competitive antagonists also affects basal peripheral sensitivity and causes sedation [41, 42].

Our findings show that purinergic P2X7 receptors are functionally linked with presynaptic AMPA receptors on glutamatergic axon terminals in the rat TCN. P2X7 receptors agonists were found to facilitate the activation of the AMPA receptors, suggesting that, in addition to provoking Glu release on its own, ATP can also regulate AMPA-mediated Glu release. The technique of up-down

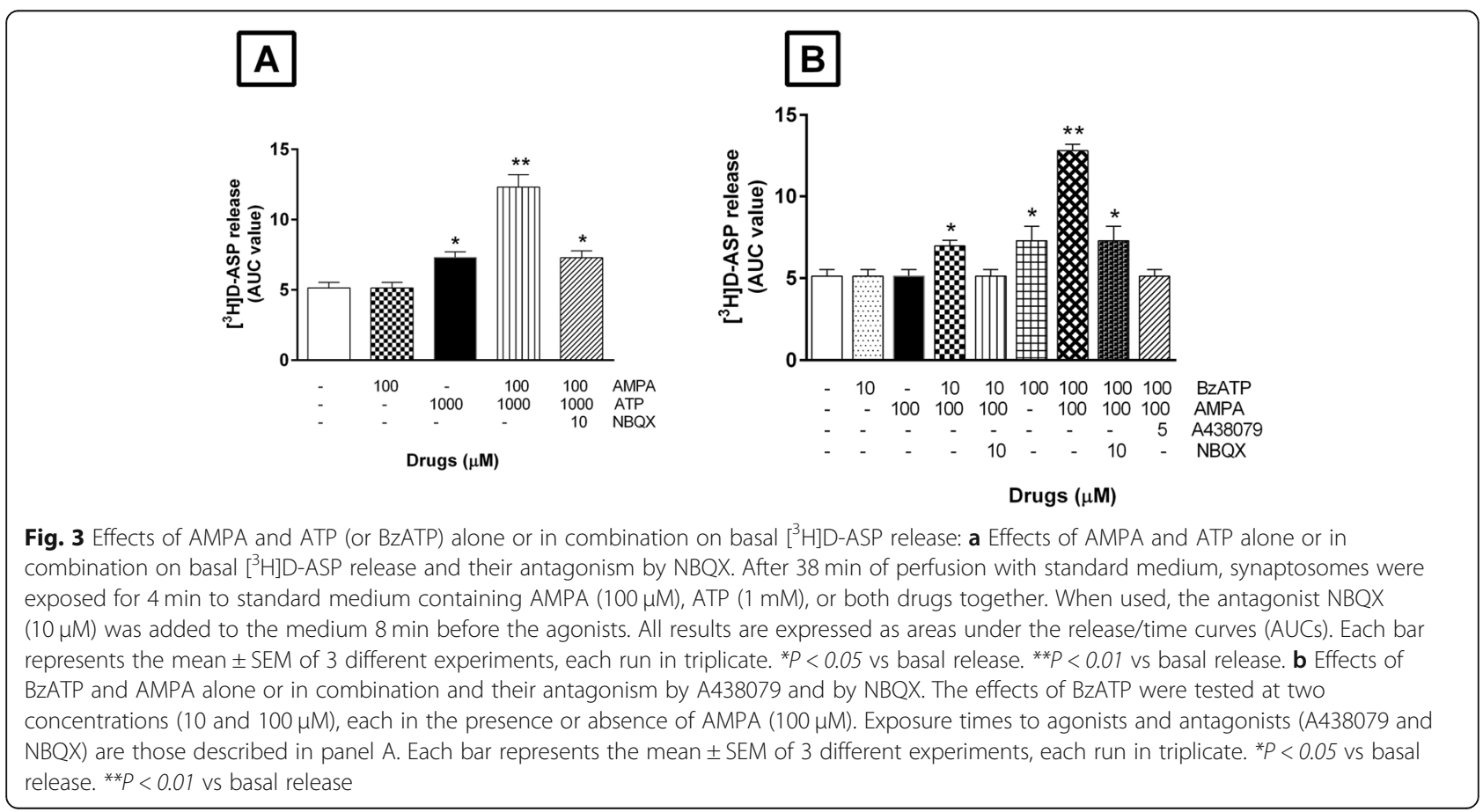


superfusion of synaptosomes used in this study has previously been exploited to identify and characterize release-regulating presynaptic receptors [33]. In our perfusion apparatus, a thin layer of synaptosomes is perfused under conditions that preclude indirect effects: the vertical movement of the perfusate rapidly removes compounds released by the nerve terminals before they can activate targets expressed by the releasing terminals themselves or by particles in the vicinity of the latter. These presynaptic targets thus remain virtually unbound by endogenous ligands and can be selectively activated by agents added to the superfusion medium.

In our experiments, ATP stimulated the release of preloaded $\left[{ }^{3} \mathrm{H}\right] \mathrm{D}$-ASP from superfused glutamatergic terminals in the rat TCN. On the basis of the results obtained, the pharmacological profile of the receptor that mediates the increase of ATP in basal $\left[{ }^{3} \mathrm{H}\right] \mathrm{D}$-ASP release from glutamatergic terminals in the TCN resembles that of the P2X7 subtype. First of all, the effects ATP were observed at millimolar concentrations [34, 36]. We can reasonably assume that in our superfusion system, where the medium is continually renewed, ATP catabolism does not significantly affect ATP concentrations. Second, both ATP and BzATP evoked $\left[{ }^{3} \mathrm{H}\right] \mathrm{D}$-ASP release, but the superior potency of the latter in this setting points strongly to the involvement of P2X7 receptors [34]. Last but not least, the response to ATP was abolished by the selective P2X7 antagonist A438079, and the response to BzATP was potentiated by the reduction of extracellular $\mathrm{Mg}^{2+}$ levels $[35,43]$.

Glutamatergic axon terminals in the rat brain express facilitatory AMPA autoreceptors capable of enhancing Glu release $[44,45]$. In the rat TCN, AMPA receptors located on glutamatergic nerve endings have been shown to facilitate $\left[{ }^{3} \mathrm{H}\right] \mathrm{D}$-ASP release during terminal depolarization [10], and their activity can be modulated by CTZ, which inhibits the rapid desensitization typical of AMPA receptors inhibiting receptor endocytosis [46]. A dynamic equilibrium is normally maintained between the number of AMPA receptors expressed at the cell membrane and cytosolic compartments [47]. It has been proposed that AMPA receptors move from and to presynaptic membranes [48], as they reportedly do at the postsynaptic level. In the spinal cord, the largest AMPA receptor populations consist of the GluA1/GluA2 and GluA2/GluA3 heteromers [49]. Under basal conditions, excitatory neurons appear to express mostly the non$\mathrm{Ca}^{2+}$-permeable GluA2 subunit $[50,51]$. AMPA receptors containing the GluA2 subunits are continuously inserted into synapses, whereas synaptic activity is required for insertion of those containing the GluA1 subunit [52, 53]. The results of our experiments are compatible with the view that glutamatergic terminals in the rat TCN express CTZ-sensitive, GluA2-containing, heteromeric AMPA-preferring autoreceptors, which translocate constitutively into and out of presynaptic plasma membranes.

We found that: (i) AMPA is unable to evoke $\left[{ }^{3} \mathrm{H}\right] \mathrm{D}$ ASP release under basal conditions; (ii) the increase in spontaneous $\left[{ }^{3} \mathrm{H}\right] \mathrm{D}$-ASP release is triggered by ATP and to an even greater extent by BzATP; (iii) the $\left[{ }^{3} \mathrm{H}\right] \mathrm{D}$-ASP release evoked by co-application of purinoceptor agonists and AMPA exceeds that elicited by application of ATP or BzATP alone; and (iv) this "excess" release is mediated by AMPA-receptor activation. As noted above, the technique we used to monitor $\left[{ }^{3} \mathrm{H}\right] \mathrm{D}$-ASP release allows us to exclude the possibility of indirect effects. We can therefore reasonably conclude that activation of P2X7 receptors is exerting a permissive effect on the activation of AMPA receptors located on the same glutamatergic terminals. Importantly, this hypothesis is supported by the fact that co-application of AMPA and the P2X7 receptor agonist BzATP - each at a concentration unable to evoke $\left[{ }^{3} \mathrm{H}\right] \mathrm{D}$-ASP release-did indeed elicit significant release of $\left[{ }^{3} \mathrm{H}\right] \mathrm{D}$-ASP, which could be prevented by the selective NBQX AMPA antagonist.

Our results suggest that activation of P2X7 receptors permits $\mathrm{Na}^{+}$and $\mathrm{Ca}^{2+}$ influx, depolarization of the nerve terminal, and stimulation of $\left[{ }^{3} \mathrm{H}\right] \mathrm{D}$-ASP release. Concentrations of the P2X7 agonist that have no effect on basal $\left[{ }^{3} \mathrm{H}\right] \mathrm{D}$-ASP release could nonetheless cause increases in cytosolic $\mathrm{Ca}^{2+}$ levels sufficient to permit activation of AMPA receptors by the following mechanism. The cytosolic proteins involved in AMPA receptor trafficking are $\mathrm{Ca}^{2+}$ sensors [54], which raises the possibility that $\mathrm{Ca}^{2+}$ ions flowing through P2X7 receptor-associated channels can transduce $\mathrm{P} 2 \mathrm{X} 7$ receptor activation into an increased presence of AMPA receptors at the level of the synaptic plasma membranes. Consequently, P2X7mediated increases in the number of AMPA receptors expressed on the presynaptic membrane would allow nerve terminal depolarization and the release of Glu.

It has been shown that ATP released from glial cells in response to the activation of $\alpha_{1}$-adrenoceptors reportedly increases the strength of glutamatergic synapses by promoting the phosphatidylinositol 3-kinase (PI3K)dependent insertion of postsynaptic AMPA receptors [55]. Understanding the function of cerebral AMPA receptors and the mechanisms underlying their regulation is important for several reasons. AMPA receptormediated glutamatergic transmission plays pivotal roles in modulating the neuronal and synaptic activities in many brain regions. In addition, the auxiliary subunits that regulate AMPA-receptor trafficking in several brain areas have been proposed as valuable therapeutic targets [56]. A clearer understanding of the mechanisms regulating the AMPA receptors involved in transmitting pain signals in specific brain areas could shed valuable light on the properties of these receptors. Our findings show 
that presynaptic AMPA receptors can be activated by nerve terminal depolarization or by the activation of P2X7 receptors co-localized on those terminals. Most nerve terminals are capable of storing and releasing ATP (as a fast co-transmitter) together with a classical fast transmitter. The role of ATP as a co-transmitter varies considerably in different species and pathological conditions, but also within neuronal systems, depending on the transmitter it partners with and the receptors involved [57]. P2X7 receptors are activated by high concentrations of ATP. It is therefore conceivable that, during states of augmented neuronal activity capable of triggering more sustained ATP release, P2X7 receptors could activate AMPA receptors and facilitate the release of Glu [58, 59].

Some investigators have suggested that P2X7 receptors might be physiologically silent, due to the low extracellular concentrations of ATP, and their expression and/or activation is restricted to pathological states (e.g., inflammation, trauma, stress), characterized by metabolic distress or cellular damage favoring an ATP-rich extracellular milieu near the receptors [60,61]. The high extracellular levels of ATP reached during such states could trigger widespread activation of P2X7 receptors, including those present in nearby astrocytes and microglia [61]. Since P2X7 receptor activation can also trigger Glu release from astrocytes [13], it is reasonable to hypothesize that ATP and Glu released by glial cells influence the neuronal release of Glu via their coactivation of presynaptic AMPA receptors. In this manner, P2X7 receptors would be capable of triggering Glu release from the nerve terminals and facilitating the transmission of nociceptive signals. P2X7 receptors have been proposed as central players in the synergic crosstalk that occurs between the neural network and nearby glial cells and serves to ensure the high-level synaptic transmission that reinforces pain signals [62]. P2X7 receptor-mediated neuronal-glial interaction could give rise to a form of plasticity involving multiple synapses: the high level of ATP release by glial cells activated during states of chronic neuropathic and/or neuroinflammatory pain would promote Glu release on a widespread scale as well as the function of specific AMPA receptors.

\section{Conclusion}

The data presented here indicate that P2X7 and AMPA receptors located on glutamatergic nerve terminals in the TCN can interact to synergically regulate Glu release. The abundant release of glial ATP that occurs during chronic neuropathic/neuroinflammatory pain promotes a diffuse increase in extracellular Glu to pathological levels by directly stimulating the release of excitatory neurotransmitter and by facilitating the function of presynaptic AMPA receptors.

\section{Abbreviations}

AMPA: Aminomethylisoxazole propionic acid; ANOVA: Analysis of variance; ATP: Adenosine triphosphate; AUC: Area under the curve; BzATP: Benzoylbenzoyl ATP; D-ASP: D-aspartic acid; GABA: Y-Aminobutyric acid; NBQX: Nitro-tetrahydrobenzo [f]quinoxaline-7-sulfonamide;

SEM: Standard error of the mean; TCN: Trigeminal caudal nucleus

\section{Acknowledgements}

Not applicable.

\section{Authors' contributions}

DC and PN conceived and designed the study; IS carried out the experiments, analyzed data, and helped write the paper; MM designed and supervised the study and wrote the manuscript. All authors read and approved the final manuscript.

\section{Funding}

The study was financed by internal funding (Fondi di Ateneo Linea D1 2019; N. R4124500867) to Pierluigi Navarra.

\section{Availability of data and materials \\ The datasets analyzed for this study are available on reasonable request to the corresponding author.}

\section{Ethics approval}

All animal experiments performed in this study were carried out in accordance with the European Community Council Directive (86/609/EEC) and were approved by the Ethics Committee of the Catholic University of the Sacred Heart (authorization n. CESA/A/38/2010/15).

Consent for publication

Not applicable.

\section{Competing interests}

The authors declare that they have no competing interests.

Received: 12 March 2020 Accepted: 29 June 2020

Published online: 02 July 2020

\section{References}

1. Burnstock G (2016) Purinergic mechanisms and pain. Adv Pharmacol 75:91137

2. Burnstock G (2007) Purine and pyrimidine receptors. Cell Mol Life Sci 64(12): 1471-1483

3. Iglesias R, Locovei S, Roque A, Alberto AP, Dahl G, Spray DC, Scemes E (2008) P2X7 receptor-Pannexin1 complex: pharmacology and signaling. Am J Physiol Cell Physiol 295(3):C752-C760

4. Sim JA, Young MT, Sung HY, Surprenant A (2004) Reanalysis of P2X7 receptor expression in rodent brain. J Neurosci 24:6307-6314

5. Chessell IP, Hatcher JP, Bountra C, Michel AD, Hughes JP, Green P, Egerton J, Murfin M, Richardson J, Peck WL, Grahames CB, Casula MA, Yiangou Y, Birch R, Anand P, Buell GN (2005) Disruption of the P2X7 purinoceptor gene abolishes chronic inflammatory and neuropathic pain. Pain 114(3):386-396

6. Andó RD, Méhész B, Gyires K, Illes P, Sperlágh B (2010) A comparative analysis of the activity of ligands acting at P2X and P2Y receptor subtypes in models of neuropathic, acute and inflammatory pain. Br J Pharmacol 159(5):1106-1117

7. Sperlágh B, Illes P (2014) P2X7 receptor: an emerging target in central nervous system diseases. Trends Pharmacol Sci 35(10):537-547

8. Gu JG, MacDermott AB (1997) Activation of ATP P2X receptors elicits glutamate release from sensory neuron synapses. Nature 389:749-753

9. Davies AJ, North RA (2009) Electrophysiological and morphological properties of neurons in the substantia gelatinosa of the mouse trigeminal subnucleus caudalis. Pain 146(1-2):214-221

10. D'Amico M, Samengo I, Navarra P, Taglialatela M, Martire M (2010) AMPA and P2X7-receptor mediated facilitation of $\left[{ }^{3} \mathrm{H}\right] \mathrm{D}$-aspartate release from nerve terminals isolated from the rat caudal brainstem. Neurochem Int 57(6):623-628

11. Deuchars SA, Atkinson L, Brooke RE, Musa H, Milligan CJ, Batten TF, Buckley NJ, Parson SH, Deuchars J (2001) Neuronal P2X7 receptors are targeted to 
presynaptic terminals in the central and peripheral nervous systems. J Neurosci 21(18):7143-7152

12. Atkinson L, Batten TF, Moores TS, Varoqui H, Erickson JD, Deuchars J (2004) Differential co-localisation of the $\mathrm{P} 2 \mathrm{X} 7$ receptor subunit with vesicular glutamate transporters VGLUT1 and VGLUT2 in rat CNS. Neuroscience 123(3):761-768

13. Duan S, Anderson CM, Keung EC, Chen Y, Chen Y, Swanson RA (2003) P2X7 receptor-mediated release of excitatory amino acids from astrocytes. $J$ Neurosci 23(4):1320-1328

14. Marcoli M, Cervetto C, Paluzzi P, Guarnieri S, Alloisio S, Thellung S, Nobile M, Maura G (2008) P2X7 pre-synaptic receptors in adult rat cerebrocortical nerve terminals: a role in ATP-induced glutamate release. J Neurochem 105(6):2330-2342

15. Basbaum Al, Bautista DM, Scherrer G, Julius D (2009) Cellular and molecular mechanisms of pain. Cell 139(2):267-284

16. Dodick D, Silberstein S (2006) Central sensitization theory of migraine: clinical implications. Headache 46(4):S182-S191

17. Cieślak M, Czarnecka J, Roszek K, Komoszyński M (2015) The role of purinergic signaling in the etiology of migraine and novel antimigraine treatment. Purinergic Signal 11(3):307-316

18. Chizh BA, Illes P (2001) P2X receptors and nociception. Pharmacol Rev 53(4): 553-568

19. Wirkener $K$, Sperlagh $B$, Illes $P$ (2007) P2X3 receptor involvement in pain states. Mol Neurobiol 36:165-183

20. Edvinsson L (2017) The trigeminovascular pathway: role of CGRP and CGRP receptors in migraine. Headache 57(2):47-55

21. Staikopoulus V, Sessle BJ, Furness JB, Jennings EA (2007) Localization of $P 2 X 2$ and $P 2 X 3$ receptors in rat trigeminal ganglion neurons. Neuroscience $144: 208-216$

22. Masterson CG, Durham PL (2010) DHE repression of ATP mediated sensitization of trigeminal ganglion neurons. Headache 50(9):14241439

23. Fabbretti E, D'Arco M, Fabbro A, Simonetti M, Nistri A, Giniatullin R (2006) Delayed upregulation of ATP P2X3 receptors of trigeminal sensory neurons by calcitonin gene-related peptide. J Neurosci 26(23): 6163-6171

24. Yegutkin GG, Guerrero-Toro C, Kilinc E, Koroleva K, Ishchenko Y, Abushik P, Giniatullina R, Fayuk D, Giniatullin R (2016) Nucleotide homeostasis and purinergic nociceptive signaling in rat meninges in migraine-like conditions. Purinergic Signal 12:561-574

25. Haanes KA, Labastida-Ramírez A, Blixt FW, Rubio-Beltrán E, Dirven CM, Hj A, Lars Edvinsson D, Maassen VanDenBrink A (2019) Exploration of purinergic receptors as potential anti-migraine targets using established pre-clinical migraine models. Cephalalgia 39(11):1421-1434

26. Karatas H, Erdener SE, Gursoy-Ozdemir Y, Lule S, Eren-Koçak E, Sen ZD, Dalkara T (2013) Spreading depression triggers headache by activating neuronal Panx1 channels. Science 339(6123):1092-1095

27. Chen SP, Qin T, Seidel JL, Zheng Y, Eikermann M, Ferrari MD, van den Maagdenberg AMJM, Moskowitz MA, Ayata C, Eikermann-Haerter K (2017) Inhibition of the P2X7-PANX1 complex suppresses spreading depolarization and neuroinflammation. Brain 140(6):1643-1656

28. Khakh BS, North RA (2006) P2X receptors as cell-surface ATP sensors in health and disease. Nature 442:527-532

29. Han SM, Ahn DK, Youn DH (2008) Pharmacological analysis of excitatory and inhibitory synaptic transmission in horizontal brainstem slices preserving three subnuclei of spinal trigeminal nucleus. J Neurosci Methods 167:221-228

30. Martire M, Castaldo P, D’Amico M, Preziosi P, Annunziato L, Tagliatatela M (2004) M channels containing KCNQ2 subunits modulate norepinephrine, aspartate, and GABA release from hippocampal nerve terminals. J Neurosci 24:592-597

31. Raiteri M (2006) Functional pharmacology in human brain. Pharmacol Rev 58:162-193

32. Raiteri L, Zappettini S, Milanese M, Fedele E, Raiteri M, Bonanno G (2007) Mechanisms of glutamate release elicited in rat cerebrocortical nerve endings by 'pathologically' elevated extraterminal $\mathrm{K}^{+}$concentrations. J Neurochem 103(3):952-961

33. Raiteri L, Raiteri M (2000) Synaptosomes still viable after 25 years of superfusion. Neurochem Res 25(9-10):1265-1274

34. North RA, Surprenant A (2000) Pharmacology of cloned P2X receptors. Annu Rev Pharmacol Toxicol 40:563-580
35. Virginio C, Church D, North RA, Surprenant A (1997) Effects of divalent cations, protons and calmidazolium at the rat P2X7 receptor. Neuropharmacology 36:1285-1294

36. Khakh BS, Burnstock G, Kennedy C, King BF, North RA, Séguéla P, Voigt $M$, Humphrey PPA (2001) International Union of Pharmacology XXIV. Current status of the nomenclature and properties of $\mathrm{P} 2 \mathrm{X}$ receptors and their subunits. Pharmacol Rev 53:107-118

37. Vikelis M, Mitsikostas DD (2007) The role of glutamate and its receptors in migraine. CNS Neurol Disord Drug Targets 6(4):251-257

38. Woolf CJ, Salter MW (2000) Neuronal plasticity: increasing the gain in pain. Science 288:1765-1769

39. Ji RR, Kohno T, Moore KA, Woolf CJ (2003) Central sensitization and LTP: do pain and memory share similar mechanisms? Trends Neurosci 26:696-705

40. Jones TL, Sorkin LS (2004) Calcium-permeable alpha-amino-3-hydroxy-5methyl-4-isoxazolepropionic acid/kainate receptors mediate development, but not maintenance, of secondary allodynia evoked by first-degree burn in the rat. J Pharmacol Exp Ther 310(1):223-229

41. Park JS, Yaster M, Guan X, Xu JT, Shih MH, Guan Y, Raja SN, Tao YX (2008) Role of spinal cord alpha-amino-3-hydroxy-5-methyl-4-isoxazolepropionic acid receptors in complete Freund's adjuvant-induced inflammatory pain. Mol Pain 4:67-78

42. Hao JX, Xu XJ (1996) Treatment of a chronic allodynia-like response in spinally injured rats: effects of systemically administered excitatory amino acid receptor antagonists. Pain 66(2-3):279-285

43. Khakh BS, North RA (2012) Neuromodulation by extracellular ATP and P2X receptors in the CNS. Neuron 76(1):51-69

44. Barnes JM, Dev KK, Henley JM (1994) Cyclothiazide unmasks AMPA-evoked stimulation of $\left[{ }^{3} \mathrm{H}\right]$-L-glutamate release from rat hippocampal synaptosomes. Br J Pharmacol 113:339-341

45. Patel DR, Croucher MJ (1997) Evidence for a role of presynaptic AMPA receptors in the control of neuronal glutamate release in the rat forebrain. Eur J Pharmacol 332(2):143-151

46. Yamada KA, Tang C (1993) Benzothiadiazides inhibit rapid glutamate receptor desensitization and enhance glutamatergic synaptic currents. J Neurosci 13:3904-3915

47. Scannevin RH, Huganir RL (2000) Postsynaptic organization and regulation of excitatory synapses. Nat Rev Neurosci 1(2):133-141

48. Pittaluga A, Feligioni M, Longordo F, Luccini E, Raiteri M (2006) Trafficking of presynaptic AMPA receptors mediating neurotransmitter release: neuronal selectivity and relationships with sensitivity to cyclothiazide. Neuropharmacology 50(3):286-296

49. Polgar E, Watanabe M, Hartmann B, Grant SG, Todd AJ (2008) Expression of AMPA receptor subunits at synapses in laminae I-III of the rodent spinal dorsal horn. Mol Pain 4:5-19

50. Kerr RC, Maxwell DJ, Todd AJ (1998) GluR1 and GluR2/3 subunits of the AMPA-type glutamate receptor are associated with particular types of neurone in laminae I-III of the spinal dorsal horn of the rat. Eur J Neurosci 10:324-333

51. Tong CK, MacDermott AB (2006) Both $\mathrm{Ca}^{2+}$-permeable and -impermeable AMPA receptors contribute to primary synaptic drive onto rat dorsal horn neurons. J Physiol 575:133-144

52. Passafaro M, Piëch $V$, Sheng M (2001) Subunit-specific temporal and spatial patterns of AMPA receptor exocytosis in hippocampal neurons. Nat Neurosci 4(9):917-926

53. Piccini A, Malinow R (2002) Critical postsynaptic density 95/disc large/ zonula occludens-1 interactions by glutamate receptor 1 (GluR1) and GluR2 required at different subcellular sites. J 49. Neurosci 22(13):53875392

54. Hanley JG, Henley JM (2005) PICK1 is a calcium-sensor for NMDA-induced AMPA receptor trafficking. EMBO J 24(18):3266-3278

55. Gordon GR, Baimoukhametova DV, Hewitt SA, Rajapaksha WR, Fisher TE, Bains JS (2005) Norepinephrine triggers release of glial ATP to increase postsynaptic efficacy. Nat Neurosci 8(8):1078-1086

56. Kato AS, Witkin JM (2018) Auxiliary subunits of AMPA receptors: the discovery of a forebrain-selective antagonist, LY3130481/CERC-611. Biochem Pharmacol 147:191-200

57. Burnstock G (2004) Cotrasmission. Curr Opin Pharmacol 4:47-52

58. Cunha RA, Vizi ES, Ribeiro JA, Sebastião AM (1996) Preferential release of ATP and its extracellular catabolism as a source of adenosine upon high- but not lowfrequency stimulation of rat hippocampal slices. J Neurochem 67(5):2180-2187 
59. Wieraszko A, Goldsmith G, Seyfried TN (1989) Stimulation-dependent release of adenosine triphosphate from hippocampal slices. Brain Res 485(2):244-250

60. Cotrina ML, Nedergaard M (2009) Physiological and pathological functions of P2X7 receptor in the spinal cord. Purinergic Signal 5(2):223-232

61. Sperlágh B, Vizi ES, Wirkner K, Illes P (2006) P2X7 receptors in the nervous system. Prog Neurobiol 78(6):327-346

62. Bennett MR, Farnell L, Gibson WG (2009) P2X7 regenerative-loop potentiation of glutamate synaptic transmission by microglia and astrocytes. J Theor Biol 261(1):1-16

\section{Publisher's Note}

Springer Nature remains neutral with regard to jurisdictional claims in published maps and institutional affiliations.

Ready to submit your research? Choose BMC and benefit from:

- fast, convenient online submission

- thorough peer review by experienced researchers in your field

- rapid publication on acceptance

- support for research data, including large and complex data types

- gold Open Access which fosters wider collaboration and increased citations

- maximum visibility for your research: over $100 \mathrm{M}$ website views per year

At BMC, research is always in progress.

Learn more biomedcentral.com/submissions 